\title{
Growth Giant Prawns (Macrobracium Rosenbergii) With Different Stock Densities On The Minapadi System
}

\author{
Mahendra $^{1 *}$, Farah Diana ${ }^{2}$, Dini Islama ${ }^{3}$, and Citra Dina Febrina ${ }^{4}$ \\ 1.2.3.4 Aquaculture Study Program, Faculty of Fisheries and Marine \\ Science, Teuku Umar University, West Aceh, Indonesia \\ *Corresponding Author: \\ Email: mahendra@utu.ac.id
}

\begin{abstract}
.
Minapadi is a fish rearing system in rice fields that is carried out with rice plants. This study aims to increase the income of farmers with high productivity of rice yields and increase the production of giant prawns. The method used is a Completely Randomized Design (CRD) experiment with 3 treatments and 3 replications. The treatments were: P1= stocking density of 100 birds/plot, P2 = stocking density of 200 birds/plot, P3 = stocking density of 300 birds/plot. This research was conducted for 90 days. Parameters observed were rice productivity and growth. The results showed that the best treatment was P2 = stocking density of $200 \mathrm{birds} / \mathrm{plot}$. by producing an average value of rice productivity of $5 \mathrm{~kg} / 50 \mathrm{~m} 2$ and an average value of growth of giant prawns of $4.72 \%$
\end{abstract}

Keywords: Growth, Macrobracium rosenbergii; Minapadi, stocking density

\section{INTRODUCTION}

The Covid-19 pandemic has caused instability in all sectors of the economy, including the fisheries and agriculture sectors, in addition to struggling to improve the economy during the COVID-19 pandemic, must also make efforts to meet the food needs of the family. Efforts that can be made to meet the food needs of the community, including cultivation [1]. For rural communities, this protein need can still be met by keeping fish in ponds, rivers, lakes or other aquatic media. Along with the development of development, fish farming land in the village is also becoming increasingly narrow. One of the activities that can be done to meet the economic and animal protein needs as the immune system of the human body is Minapadi.Minapadi is a system of growing rice and cultivating fish in one rice field simultaneously. This technology aims to increase the income of farmers with high productivity of rice yields and increase local fish production [2].

One of the fish that is suitable to be kept in the Minapadi system is local tilapia and giant prawns which are some of Aceh's endemic fish [3] which are potential fish for Aceh.Giant prawns are one of the most potential aquatic biota to be reared in the Minapadi system. The application of the Minapadi system with giant prawns has been implemented by the research team which has very good growth in the Nagan Raya area [2], however, the stocking density is still unknown which is good for shrimp growth 
and rice productivity. Based on the above, the authors are interested in conducting research on the topic "Growth of giant prawns with different stocking densities in the Minapadi system"

\section{METHODS}

This research was conducted in the rice fields of Pante Ceureumen District, West Aceh Regency from preparation to data collection. The method used in this study is an experimental method and the design used is a Completely Randomized Design (CRD) consisting of 3 treatments with 3 replications each. The treatment of each material used in this study includes:

$\mathrm{P} 1=$ Stocking density of 100 heads/plot

P2 $=$ Stocking density of 200 heads/plot

P3 = Stocking density of 300 heads/plot

This research was conducted in a rice field area with a total of 9 plots with an area per plot of $5 \times 10$ meters. Make a rice field bund with a height of $60 \mathrm{~cm}$, a base width of 60 $\mathrm{cm}$ and an upper width of $30 \mathrm{~cm}$. While the trench (kemalir) according to the Legowo system treatment with the size: $30-60 \mathrm{~cm}$ wide, $40 \mathrm{~cm}$ deep. Planting is done by transplanting (tapin).

Rice is planted after 30 days. The variety used is resistant to waterlogging and pest attack, namely MAPAN. Spacing $25 \times 12.5 \mathrm{~cm}$. The number of seedlings planted 2 - 3 stems per clump. The water level is $10 \mathrm{~cm}$. Shrimp stocking was done when the plants were 30 days old with a water level of $10 \mathrm{~cm}$. Stocking density was carried out according to the treatment. Stocking is done in the afternoon to avoid stress fish. The duration of shrimp rearing in the Minapadi system is 90 days with feeding 3 times a day, namely in the morning, afternoon and evening. The maximum dose given is $3 \%$ of the total biomass with the frequency of administration. Shrimp harvest is done 90 days after planting rice. Observation of rice seen from its productivity. While shrimp is seen from its growth and survival

Productivity rice according to [4] is calculated using the formula:

$$
\text { Produktivitas padi }=\frac{\text { Jumlah produksi }(\mathrm{Kg})}{\text { Luas lahan }(\mathrm{ha})}
$$

According to [5], the relative growth rate of fish is calculated using the following formula:

Information:

$$
\mathrm{RGR}=\frac{\mathrm{Wt}-\mathrm{W} 0}{\mathrm{~W} 0 \times \mathrm{t}} \times 100 \%
$$

$$
\begin{array}{ll}
\mathrm{SGR} & =\text { Growth rate Relatively } \\
\mathrm{Wt} & =\text { Weight fish end of research } \\
\mathrm{W} 0 & =\text { Weight fish start research } \\
\mathrm{t} & =\text { Research time (length of research) }
\end{array}
$$


The data obtained will be grouped, tabulated, performed statistical tests ANOVA and SPSS to see the effect of the experiment. If there is a significant difference, a further Tukey test will be carried out

\section{RESULTS AND DISCUSSION Rice productivity}

The results obtained from research on rice productivity during maintenance can be seen in Figure 1 below. Productivity is the process of converting factors of production into a product. Productivity reflects the ratio between total production and land area. The results of the study based on Figure 1 showed that the highest rice productivity value in this study was $\mathrm{P} 1$ treatment with a value of $5 \mathrm{~kg} / \mathrm{plot}$. While the lowest in the P3 treatment was $4 \mathrm{~kg} / \mathrm{plot}$. According to research [6] that with the same paddy field area with the proportion of fish cultivation by $10 \%$ and the proportion of Minapadi by $90 \%$ there was an increase in land productivity from $5,652 \mathrm{~kg} / \mathrm{ha}$ to 7,612 $\mathrm{kg} / \mathrm{ha}$.

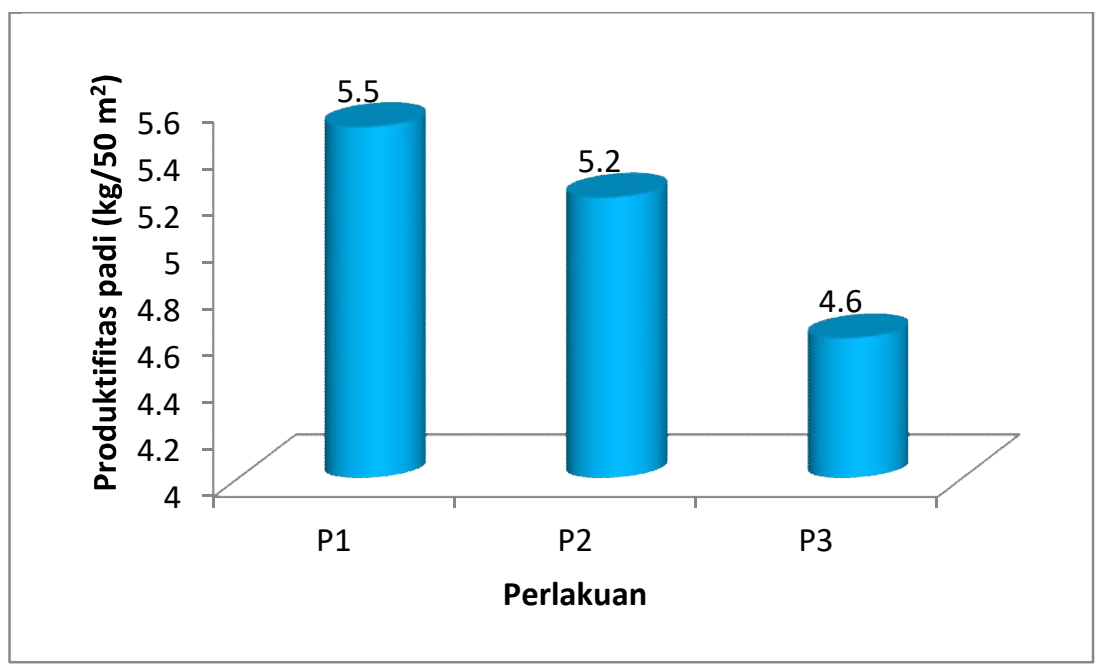

Fig 1. Rice Productivity

The process of converting production factors into a product and reflecting the ratio between total production and land area is an understanding of productivity. The results of the study based on Figure 2 showed that the highest rice productivity value in this study was P1 treatment with a value of $5 \mathrm{~kg} / \mathrm{plot}$. While the lowest in the P3 treatment was $4 \mathrm{~kg} / \mathrm{plot}$. According to [7] Minapadi cultivation is said to be successful when rice production is at least the same as production before Minapadi. The ability of land in production is getting better when implementing Minapadi. Efforts to increase productivity are achieved through improving soil conditions and intensive handling of pests and weeds.

The high productivity of rice in the P1 treatment is suspected to be pellet feed given the pellets given are not consumed by shrimp, because there is still an abundance 
of natural feed that is preferred by shrimp, so that the finished pellets will accumulate to become fertilizer which is absorbed by rice plants. According to [8] nitrogen is absorbed by plant roots in the form of NO3 - (nitrate) and NH4 + (ammonium). Nitrogen is the main nutrient for plant growth. Nitrogen deficiency can be bad for plants such as stunted plant growth, yellowing of plant leaves, and limited root system, while excess nitrogen causes vegetative growth to be elongated, easy to fall, reduce grain quality and response to pests and diseases. While pellets contain $\mathrm{N}$ elements which cause more effective rice growth.

\section{Relative Growth Rate}

The results of the relative growth rate of giant prawns in each treatment and replication for 90 days of rearing period are presented in Figure 1.

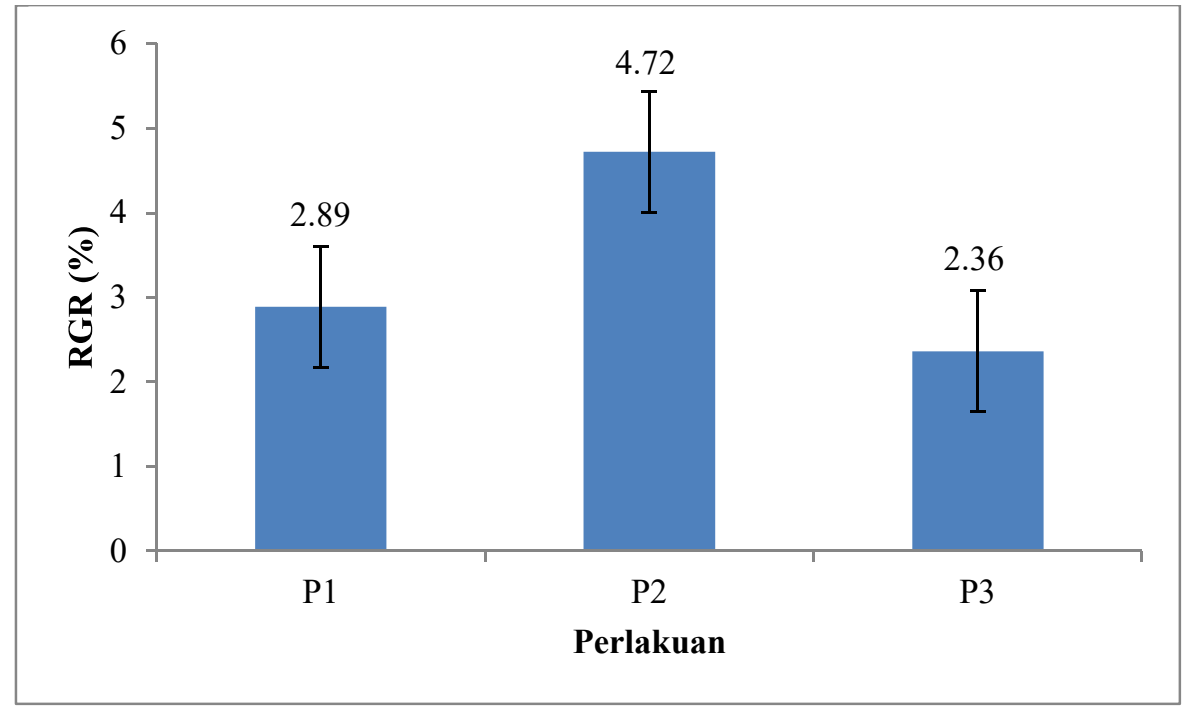

Fig 2. Relative growth rate of giant prawns

The results of the study based on Figure 2 show that the lowest relative growth rate value in this study was the P3 treatment with a value of $2.36 \%$. Meanwhile, the highest relative growth rate was found in $\mathrm{P} 2$ treatment with a value of $4.72 \%$. The results of this study indicate that different stocking densities in the Minapadi system play a role in supporting the growth of giant prawns.A stocking density of 200/plot is more effective with a size of $50 \mathrm{~m} 2$, compared to a stocking density of 100 and 300 , because the higher the stocking density will affect the competition for feed consumption, oxygen and space for the shrimp. So that the stocking density of pa P2 is more effective. While the stocking density of 100 heads / plot is the least, but the growth is less effective, it is suspected that the feed in the form of pellets given is not consumed by the shrimp, because there is still an abundance of natural feed which is preferred by the shrimp, so that the remaining pellets will accumulate into absorbed fertilizer. by rice plants.

It can be seen in the productivity of rice that rice plants in P1 treatment were higher than other treatments.Regeneration, metamorphosis and moulting are some 
aspects of physiological processes related to individual growth. In crustaceans such as giant prawns, moulting is a process of periodically releasing old shells and forming new, larger shells. Body weight gain will be hampered if it is not preceded by the molting process [9].High growth is characterized by a faster moulting process. The process of transferring minerals from hemolymph to shrimp shells requires a lot of energy. This large energy requirement is obtained from the feed consumed. Feeding is an energy requirement to support faster growth. This is closely related to growth where if feed consumption is high, there is a lot of energy available that can be used for various life needs and by reducing energy expenditure, so that the portion of energy available for growth is greater. If the physiology of shrimp goes well, including metabolism, then the utilization of feed is more efficient which ultimately increases growth [10]

\section{CONCLUSION}

Different stocking densities affected the growth of giant prawns with the best stocking density of $200 \mathrm{fish} /$ plot which resulted in the growth of giant prawns of $4.72 \%$ and average rice productivity of $5 \mathrm{~kg} /$ plot..

\section{ACKNOWLEDGMENTS}

The author's research was funded by internal research grants from Teuku Umar University, especially LPPM and Quality Assurance as well as the Aquaculture Study Program, Faculty of Fisheries and Marine Sciences.

\section{REFERENCES}

[1] Saputri, SAD and Rachmawatie, D. 2020. Fish Cultivation in Buckets: A Family Strategy in Order to Strengthen Food Security Amid the Covid-19 Pandemic. Journal of Agricultural Sciences Tirtayasa, 2(1): 102-109

[2] Mahendra., Saputra F., Febrina CD, and Islama D. 2019. Millennial Technology (Minapadi Legowo With Local Fish) in a Sustainable Way in Beutong Nagan Raya District. Journal of Community Service. 3(2): 286 - 298

[3] Aceh Maritime Affairs and Fisheries Service. 2015. Identification of Endemic Fish Species in Aceh Waters South West Region (West Aceh). Final report. Banda Aceh

[4] Silamat, E., Yuwana., and Yuliarso, MZ 2014. Analysis of Paddy Rice Farming Productivity Using Hand Tractors and Conventional Methods in Rejang Lebong Regency. Bengkulu University. ISSN: 1412-8837

[5] Thu, EVT, Rahman, M., Phoo, WW, and Kim CH 2019. Salinity Effects on Growth and Survival of the Polychaete Rockworm Marphysa sanguinea (Montagu, 1813) Juveniles and Adults. Journal of Aquaculture Research \& Development. 10(2): 1-7

[6] Julistia, DR 2017. Analysis of Minapadi Farming Income in Margoluwih Village, Seyegan District, Sleman Regency. [Essay]. Bogor: Bogor Agricultural University.

[7] Tysno, LFI 2018. Analysis of Minapadi Farming Income. [Essay]. Bogor: Bogor Agricultural University 
[8] Kaya, E. 2013. Effect of Straw Compost and NPK Fertilizer on N-Available Soil, NUptake, Growth, and Yield of Paddy Rice (Oryza sativa L). Agrologia, 2 (1): 43-50

[9] Affandi, R. and Tang, UM. 2002. Physiology of Aquatic Animals. Riau University, Riau.

[10] Zaidy, $\mathrm{AB}$ 2007. Utilization of Aquatic Calcium in the Molting Process and Its Consequences for the Growth of Giant Prawns (Macrobrachium rosenbergii de Man). Dissertation. Bogor Agricultural University, Bogor 